\title{
Effect of transcutaneous electrical nerve stimulation on vertebral metastatic bone pain of breast cancer patients: single case experimental study
}

\author{
Efeito da estimulação elétrica nervosa transcutânea na dor óssea metastática vertebral em \\ mulheres com câncer de mama: estudo experimental de caso único
}

Luciana Ribeiro Sampaio ${ }^{1}$, Marcos Antonio de Resende ${ }^{1}$, Leani Souza Maxima Pereira ${ }^{1}$

DOI 10.5935/1806-0013.20160020

\section{ABSTRACT}

BACKGROUND AND OBJECTIVES: To evaluate the analgesic efficacy of transcutaneous electrical nerve stimulation on vertebral metastatic bone pain of breast cancer patients and its impact on analgesic consumption.

METHODS: A single case experimental design was used where three females aged between 40 and 60 years were selected. Design was A1-B-A2-C-A3-D-A4, where in phase A participants received no intervention, in phase $B$ they received high frequency transcutaneous electrical nerve stimulation, in phase $\mathrm{C}$ low frequency transcutaneous electrical nerve stimulation and in phase $\mathrm{D}$, transcutaneous electrical nerve stimulation turned off - placebo. Each baseline phase lasted 7 days (A: no intervention) and phases B, C and D lasted 10 days (with intervention). Analgesic consumption and pain were evaluated with the visual analog scale. Data were analyzed with Mann-Whitney test to compare analgesic consumption. For visual analog scale analysis, split-middle line and binomial tests were used to verify difference between baseline and intervention phases, considering significant $\mathrm{p}<0.05$.

RESULTS: There has been significant analgesic consumption decrease in $66.6 \%$ of volunteers after high frequency transcutaneous electrical nerve stimulation and in $33.3 \%$ after low frequency transcutaneous electrical nerve stimulation. Pain intensity by the visual analog scale was decreased in $100 \%$ of volunteers receiving low frequency transcutaneous electrical nerve stimulation, in $33.3 \%$ of those receiving high frequency transcutaneous electrical nerve stimulation and in $33.3 \%$ of those receiving transcutaneous electrical nerve stimulation turned off (placebo), between interventions and their respective previous baselines. In $66.6 \%$ of participants there has been significant difference

1. Universidade Federal de Minas Gerais, Hospital das Clínicas, Departamento de Fisioterapia, Belo Horizonte, MG, Brasil.

Submitted in January 29, 2016.

Accepted for publication in April 18, 2016.

Conflict of interests: none - Sponsoring sources: none.

Correspondence to:

Av. Antônio Carlos, 6627 - Campus Pampulha

31270-901 Belo Horizonte, MG, Brasil.

E-mail: lusampaio_hc@yahoo.com.br

(C) Sociedade Brasileira para o Estudo da Dor of high frequency transcutaneous electrical nerve stimulation compared to their posterior baselines, as well as in $33.3 \%$ when comparing transcutaneous electrical nerve stimulation turned off (placebo) and their respective posterior baseline.

CONCLUSION: Results suggest that both high and low frequency transcutaneous electrical nerve stimulations may contribute as adjuvant in controlling metastatic vertebral bone pain and decreasing analgesic consumption in breast cancer patients. Keywords: Breast cancer, Electric therapy, High and low frequency transcutaneous electrical nerve stimulation, Metastasis.

\section{RESUMO}

JUSTIFICATIVA E OBJETIVOS: Avaliar a eficácia analgésica da estimulação elétrica nervosa transcutânea na dor óssea metastática vertebral em mulheres com câncer de mama e seu impacto no consumo de analgésicos.

MÉTODOS: Foi utilizado um desenho experimental de caso único, onde foram selecionadas três mulheres com idade entre 40 e 60 anos. O desenho utilizado foi A1-B-A2-C-A3-D-A4, no qual as participantes na fase $A$ não receberam intervenção, na fase $B$ receberam estimulação elétrica nervosa transcutânea de alta frequência, na fase $C$, estimulação elétrica nervosa transcutânea de baixa frequência e na fase $\mathrm{D}$, estimulação elétrica nervosa transcutânea desligado-placebo. Cada fase baseline durou 7 dias (A: sem intervenção) e 10 dias para B,C e D (com intervenção). Foi avaliado o consumo de analgésicos e a dor, pela escala analógica visual. A análise de dados foi realizada pelo teste Mann-Whitney para comparaçáo do consumo de analgésicos. Para análise da escala analógica visual foram utilizados os testes split-middle line e o binomial para verificar a diferença entre as fases baseline e intervenção, considerando-se significativo quando $\mathrm{p}<0,05$.

RESULTADOS: Houve reduçáo significativa no consumo do fármaco analgésico em 66,6\% das voluntárias após aplicação da estimulação elétrica nervosa transcutânea de alta frequência e em 33,3\% após a estimulação elétrica nervosa transcutânea de baixa frequência. A intensidade da dor pela escala analógica visual foi reduzida em 100\% das voluntárias que receberam estimulação elétrica nervosa transcutânea de baixa frequência; em 33,3\% que receberam estimulação elétrica nervosa transcutânea de alta frequência e em 33,3\% que receberam estimulação elétrica nervosa transcutânea desligada (placebo), entre as intervençóes e seus respectivos baselines anteriores. Em 66,6\% das participantes, 
houve diferença significativa da estimulação elétrica nervosa transcutânea de alta frequência comparada aos seus baselines posteriores, assim como em 33,3\% na comparação da estimulação elétrica nervosa transcutânea desligada (placebo) e seu respectivo baseline posterior.

CONCLUSÁO: Os resultados sugerem que estimulação elétrica nervosa transcutânea de alta e baixa frequência podem contribuir como coadjuvante no controle da dor óssea vertebral metastática e reduzir o consumo de medicamento analgésico em mulheres com câncer mamário.

Descritores: Câncer de mama, Eletroterapia, Estimulação elétrica nervosa transcutânea alta e baixa frequência, Metástase.

\section{INTRODUCTION}

Pain is a frequent symptom of malignant tumors, especially when there is bone metastasis. It is probably a major responsible for decreased quality of life (QL) and may increase depressive and/or anxious symptoms leading to daily life activities limitation ${ }^{1}$. Metastatic breast cancer (BC) is incurable so its treatment is palliative aiming at pain relief and at improving patients' $\mathrm{QL}^{2}$.

Physiotherapeutic management of breast carcinoma patients involves pre, immediate and late postoperative periods and pain is controlled with resources such as transcutaneous electrical nerve stimulation (TENS). TENS is noninvasive, easy to apply and may be used in young, adult and elderly patients aiming at inducing analgesia. It has no adverse effects and very few contraindications, in addition to not being expensive ${ }^{3}$. TENS analgesic mechanisms are based on the spinal gate theory proposed by Melzack and Wall, and on the participation of pain inhibitory descending system, which modulates the activity of pain transmission neurons located in spinal cord dorsal horn and electrical cortical effects on sensory motor cortex ${ }^{4-6}$.

There are few studies in the literature ${ }^{7-11}$ comparing TENS effects in its different frequencies and placebo for metastatic bone pain of cancer patients. On the other hand, TENS is an old and widely used physiotherapeutic resource for acute and chronic pain of several diseases ${ }^{3}$.

This study aimed at evaluating the analgesic efficacy of low and high frequency TENS to control metastatic vertebral bone pain of $\mathrm{BC}$ patients.

\section{METHODS}

This was a single case or intra-subjects design experimental study. A reversion design was used, or type A1-B-A2-CA3-D-A4, where phase A: baseline (without intervention or control condition), phase B: application of high frequency TENS (HF), phase C: application of low frequency TENS (LF) and phase D: application of placebo TENS. This design consists of making successive comparisons between control conditions and experimental conditions in a same experiment, allowing the comparison of each intervention phase $(B, C, D)$ and subsequent baseline phases, that is, this design is aimed at showing the effects of an independent variable by removing one condition and by reintroducing other already presented condition (reversion to previous condition) and this is why such designs are called reversion designs ${ }^{12,13}$. Phases lasted seven days in the baseline period (A) and 10 days for each intervention pe$\operatorname{riod}(\mathrm{B}, \mathrm{C}, \mathrm{D})$.

Initially, six women were selected to participate in the study, being three excluded from this total, two due to traveling difficulties and one for not having frequent pain during the first baseline. So, three volunteers with BC and metastatic vertebral bone disease have completed all phases. The study was carried out in the Ambulatory Borges da Costa, Hospital das Clínicas, Universidade Federal de Minas Gerais (UFMG).

Inclusion criteria were: a) age between 40 and 60 years; b) oncologic disease stage IV according to TNM classification, where $\mathrm{T}$ represents primary tumor, $\mathrm{N}$ represents the dimension of regional lymph nodes involvement and $M$ represents the presence or not of distant metastasis; c) complaint of refractory pain due to vertebral bone metastasis confirmed by bone scintigraphy, for at least three months, even under pharmacological analgesic treatment; d) participants should be under oncologic treatment for at least three months without changes in hormonal or chemotherapeutic schedule or other systemic therapy for baseline disease; e) participants submitted to radiotherapy to treat bone metastasis should have completed therapy at least one month ago.

Exclusion criteria were: a) being in terminal stage of the disease, when volunteers would be unable to understand and/or perform a procedure when asked to; b) being hospitalized; c) having no tactile sensitivity.

TENS device was a Neurodyn III type equipment, previously gauged, with four self-adhesive silicone electrodes size $9 \mathrm{~cm} \times 5 \mathrm{~cm}$ which were placed around the painful region. Stimulation parameters were: low frequency $(10 \mathrm{~Hz})$ and high frequency $(130 \mathrm{~Hz})^{14,15}$. Turned off TENS (placebo) was also used in the study, which had a light sign but no electrical current. Pulse duration was established as $130 \mathrm{msec}$ and intensity at sensory level, with application time of 30 minutes. Electrical stimulation was applied during 10 days, only interrupting intervention during weekends.

Visual analog scale (VAS) was used to evaluate pain intensity. This scale is a $10 \mathrm{~cm}$ ruler were zero means no pain and the other edge of the ruler means maximum pain. Participant would mark a point on the ruler that best represented pain intensity at that moment. This tool is widely used in studies to evaluate acute and chronic pain, including oncologic pain ${ }^{16}$. According to these authors, VAS is highly reliable $(\mathrm{CCI}=0.82)$ and has very god internal validity, $\alpha$ Chronbach $>0.80^{16}$

Analgesic consumption of each participant was daily recorded during all study phases. Participants would record analgesic drug name, dose, time and frequency every day. All participants were also evaluated by Beck Inventory to 
characterize the sample with regard to depressive symptoms. Questionnaire was made up of 21 depression-related items with scores varying from zero to 3 . This questionnaire was translated into Brazilian Portuguese language and validated by Andrade et al. ${ }^{17}$ and has good internal consistency ( $\alpha$ Chronbach $=0.86$ ).

All participants have initially answered a questionnaire to characterize their socio-demographic profile and analysis of pain characteristics. Then, they have answered to Beck Inventory to check the presence and level of depression before the study.

Participants were explained that they would be submitted to three types of TENS interventions, when their pain would be recorded by VAS, which was also previously explained. Participants were asked to daily record analgesic drug dose, time and frequency.

VAS was daily scored in the baseline period once a day, when participants were asked to record the worst pain of the day. During TENS interventions, VAS scores were recorded approximately 10 minutes after intervention. After the turned off TENS phase, VAS and analgesic drug ingestion were followed up for seven days (A4; follow-up). All 10 intervention sessions with each stimulation modality were weekly performed from Monday to Friday, emulating clinical practice, in a total data collection period of 10 weeks.

During TENS application a best comfortable position was observed for all participants. Participants with low back pain would receive TENS in the prone position with abdominal support. Those with chest and upper limb pain would receive TENS in the sitting position. Electrical stimulation was applied in the region with worst pain complaint and the same site was maintained throughout the study.

\section{Statistical analysis}

Since data had no normal distribution (Shapiro-Wilk, $\mathrm{p}<0.05$ ) non-parametric techniques were used for statistical analysis. Non-parametric Mann-Whitney test was used to compare the distribution of drug consumption in each intervention phase to previous baseline ${ }^{13}$.

A specific method for the single case experimental study design was used to check differences on VAS analysis among phases. Baseline stability assumptions (confirmed by variation coefficient below $30 \%$ ) and the lack of self-correlation among measurements were verified ${ }^{12,13}$.

Split-middle line method was used to estimate baseline data trend, showing the direction of changes of such data with regard to the next phase by means of a trend line, which is shift in a way that half the baseline scores are located above and half below it, and extended to the next intervention phase. Binomial test was used to check statistically significant differences among measurements of each intervention phase as compared to previous baseline phase ${ }^{13}$. For all tests, results were considered significant when $\mathrm{p}<0.05$.

This study was approved by the Research Ethics Committee, UFMG, under opinion 293/06 and is in compliance with the Declaration of Helsinki. All participants have signed the Free and Informed Consent Term (FICT).

\section{RESULTS}

Demographic data and clinical profile of participants are shown in table 1.

Comparisons were made to analyze analgesic consumption between adjacent phases (A1 and B; A2 and C; $\mathrm{A} 3$ and $\mathrm{D}$; $\mathrm{D}$ and $\mathrm{A} 4$ ), for each participant, analyzing total opioid and non-opioid consumption. There has been no statisti-

Table 1. Clinical and demographic profile of participants

\begin{tabular}{|c|c|c|c|}
\hline & Participant 1 & Participant 2 & Participant 3 \\
\hline Age (years) & 52 & 46 & 54 \\
\hline Education & $7^{\text {th }}$ grade & High school & $4^{\text {th }}$ grade \\
\hline Disease staging & IV & IV & IV \\
\hline Oncologic treatment & $\begin{array}{l}\text { Tamoxifen } \\
\text { Aradia }\end{array}$ & $\begin{array}{l}\text { Arimidex } \\
\text { Aredia }\end{array}$ & $\begin{array}{l}\text { Letrozole } \\
\text { Aredia }\end{array}$ \\
\hline Metastases & Bone, lumbar spine & Bone, lumbar spine, left pelvis & Boné, thoracic spine, right umeral plexus \\
\hline Mastectomy & No & Yes & Yes \\
\hline Beck Inventory & Not depressed & Moderate depression & Marked depressison \\
\hline Antidepressant & No & Venlafaxine & Amitriptyline \\
\hline $\begin{array}{l}\text { Pain (site) } \\
\text { Beginning } \\
\text { Pattern } \\
\text { Intensity } \\
\text { Analgesics }\end{array}$ & $\begin{array}{l}\text { Lumbar spine/ right pelvis } \\
2 \text { years } \\
\text { Continuous stable/constant } \\
\text { Worsens with effort (moderate) } \\
\text { Diclofenac } \\
\text { (100mg) } \\
\text { Dipirone (500mg) } \\
\text { (sporadic use) }\end{array}$ & $\begin{array}{l}\text { Lumbar spine/left pelvis } \\
1 \text { year } \\
\text { Continuous stable/constant } \\
\text { Worsens with effort (severe) } \\
\text { Codeine } 30 \mathrm{mg} / \quad \text { paracetamol } \\
500 \mathrm{mg}, 8 / 8 \mathrm{~h} \\
\text { Dipirone }(500 \mathrm{mg}) 4 / 4 \mathrm{~h}\end{array}$ & $\begin{array}{l}\text { Thoracic spine/RUL } \\
1 \text { year } \\
\text { Continuous stable/constant } \\
\text { Worsens with effort (unbearable) } \\
\text { Methadone }(10 \mathrm{mg}) 8 / 8 \mathrm{~h} \\
\text { dipirone }(500 \mathrm{mg}) 4 / 4 \mathrm{~h}\end{array}$ \\
\hline
\end{tabular}


cally significant difference in any phase for participant 1 ( $p>0.05)$. For participant 2 there has been statistically significant difference between phases $A 1$ and $B(p<0.001)$ and between phases $A 2$ and $C(p=0.015)$. For participant 3 there has been statistically significant difference between phases A1 and $B(p<0.001)$.

Drug consumption by volunteers during different studied phases is shown in table 2 .

Analyses were performed between study phases $\mathrm{A} 1$ and $\mathrm{B}$; $\mathrm{A} 2$ and $\mathrm{C} ; \mathrm{A} 3$ and $\mathrm{D} ; \mathrm{B}$ and $\mathrm{A} 2 ; \mathrm{C}$ and $\mathrm{A} 3$; D and A4, that is, all interventions were compared to their previous and next baselines. For such comparisons, data recorded after TENS intervention were considered. Baseline phases variability evaluation has shown that they were approximately stable, not going beyond variation coefficient of 30\%. Sample descriptive statistics, or VAS values of each phase, are shown in table 3 .

There has been significant difference for participant 1 in phase B (TENS HF) with baseline A1 ( $p=0.001)$, and C (TENS LF) with baseline A2 ( $p=0.001)$ and among 3 interventions and their next baselines, that is, between phase $B$ with A2, C with A3 and D with A4, with $\mathrm{p}=0.008$.

There has been significant difference for participant 2 between phase C (TENS LF) and its previous baseline, A2 ( $\mathrm{p}=0.044)$, and between interventions $\mathrm{B}$ (TENS HF) and baseline A2 and $\mathrm{C}$ with baseline $\mathrm{A} 3$, and $\mathrm{D}$ with $\mathrm{A} 4$, with $\mathrm{p}=0.008$.

A significant difference was found in comparisons between previous baseline, A2, and intervention C (TENS
Table 3.Visual analog scale scores between baseline phases and intervention with transcutaneous electrical nerve stimulation.

\begin{tabular}{|c|c|c|c|c|}
\hline Participant & Phase & $\mathrm{X} \pm \mathrm{SD}$ & Minimum & Maximum \\
\hline \multirow[t]{7}{*}{1} & $\mathrm{~A} 1$ & $9,7 \pm 0,8$ & 8,0 & 10,0 \\
\hline & TENS HF & $3,5 \pm 1,5$ & 2,0 & 7,0 \\
\hline & $\mathrm{A} 2$ & $8,5 \pm 1,2$ & 6,8 & 10,0 \\
\hline & TENS LF & $1,5 \pm 0,9$ & 0,5 & 3,5 \\
\hline & A3 & $8,1 \pm 1,3$ & 6,5 & 10,0 \\
\hline & TENS TO & $2,5 \pm 0,7$ & 1,5 & 3,5 \\
\hline & A4 & $4,8 \pm 0,2$ & 4,5 & 5,0 \\
\hline \multirow[t]{7}{*}{2} & $\mathrm{~A} 1$ & $4,7 \pm 0,8$ & 3,5 & 5,6 \\
\hline & TENS HF & $0,8 \pm 0,6$ & 0,0 & 2,0 \\
\hline & A2 & $4,8 \pm 0,8$ & 3,5 & 5,5 \\
\hline & TENS LF & $0,5 \pm 0,7$ & 0,0 & 1,8 \\
\hline & A3 & $3,8 \pm 0,8$ & 3,0 & 5,3 \\
\hline & TENS TO & $3,4 \pm 0,5$ & 2,5 & 4,0 \\
\hline & A4 & $4,7 \pm 0,8$ & 3,5 & 5,5 \\
\hline \multirow[t]{7}{*}{3} & $\mathrm{~A} 1$ & $4,7 \pm 0,7$ & 3,8 & 5,6 \\
\hline & TENS HF & $1,2 \pm 1,5$ & 0,0 & 4,6 \\
\hline & $\mathrm{A} 2$ & $6,7 \pm 1,6$ & 4,5 & 8,5 \\
\hline & TENS LF & $1,9 \pm 1,4$ & 0,0 & 4,2 \\
\hline & A3 & $6,6 \pm 1,5$ & 4,5 & 9,1 \\
\hline & TENS TO & $3,9 \pm 2,0$ & 1,3 & 7,0 \\
\hline & A4 & $4,2 \pm 0,7$ & 3,5 & 5,7 \\
\hline
\end{tabular}

$\mathrm{X} \pm \mathrm{SD}=$ Mean \pm Standard deviation; A1, A2, A3, A4 = Baselines; TENS HF $=$ high frequency transcutaneous electrical nerve stimulation; TENS LF = low frequency transcutaneous electrical nerve stimulation; TENS TO = turned-off transcutaneous electrical nerve stimulation.

Table 2. Drug consumption by studied phase

\begin{tabular}{|c|c|c|c|c|c|c|c|}
\hline \multirow[t]{2}{*}{ Participant } & \multirow[t]{2}{*}{ Phase } & \multicolumn{2}{|c|}{ Total drug } & \multicolumn{2}{|c|}{ Opioids } & \multicolumn{2}{|c|}{ Non opioids } \\
\hline & & $\mathrm{X} \pm \mathrm{DP}$ & $\mathrm{p}$ value & $\mathrm{X} \pm \mathrm{SD}$ & $p$ value & $X \pm S D$ & $\mathrm{p}$ value \\
\hline \multirow[t]{7}{*}{1} & A1 & $29 \pm 49$ & & $0 \pm 0$ & & $29 \pm 49$ & \\
\hline & TENS HF & $0 \pm 0$ & 0,154 & $0 \pm 0$ & 1,000 & $0 \pm 0$ & 0,154 \\
\hline & A2 & $43 \pm 54$ & & $0 \pm 0$ & & $43 \pm 54$ & \\
\hline & TENS LF & $0 \pm 0$ & 0,051 & $0 \pm 0$ & 1,000 & $0 \pm 0$ & 0,051 \\
\hline & A3 & $29 \pm 49$ & & $0 \pm 0$ & & $29 \pm 49$ & \\
\hline & TENS TO & $20 \pm 42$ & 1,000 & $0 \pm 0$ & 1,000 & $20 \pm 42$ & 1,000 \\
\hline & A4 & $0 \pm 0$ & 0,485 & $0 \pm 0$ & 1,000 & $0 \pm 0$ & 0,485 \\
\hline \multirow[t]{7}{*}{2} & A1 & $2009 \pm 15$ & & $9 \pm 15$ & & $2000 \pm 0$ & \\
\hline & TENS HF & $350 \pm 669$ & $<0,001$ & $0 \pm 0$ & 0,154 & $350 \pm 669$ & $<0,001$ \\
\hline & $\mathrm{A} 2$ & $286 \pm 267$ & & $0 \pm 0$ & & $286 \pm 267$ & \\
\hline & TENS LF & $0 \pm 0$ & 0,015 & $0 \pm 0$ & 1,000 & $0 \pm 0$ & 0,015 \\
\hline & A3 & $0 \pm 0$ & & $0 \pm 0$ & & $0 \pm 0$ & \\
\hline & TENS TO & $0 \pm 0$ & 1,000 & $0 \pm 0$ & 1,000 & $0 \pm 0$ & 1,000 \\
\hline & A4 & $143 \pm 244$ & 0,154 & $0 \pm 0$ & 1,000 & $143 \pm 244$ & 0,154 \\
\hline \multirow[t]{7}{*}{3} & A1 & $2040 \pm 0$ & & $40 \pm 0$ & & $2000 \pm 0$ & \\
\hline & TENS HF & $460 \pm 158$ & $<0,001$ & $10 \pm 0$ & $<0,001$ & $450 \pm 158$ & $<0,001$ \\
\hline & $\mathrm{A} 2$ & $234 \pm 267$ & & $20 \pm 0$ & & $214 \pm 267$ & \\
\hline & TENS LF & $68 \pm 155$ & 0,088 & $18 \pm 4$ & 0,485 & $50 \pm 158$ & 0,250 \\
\hline & A3 & $84 \pm 188$ & & $13 \pm 5$ & & $71 \pm 189$ & \\
\hline & TENS TO & $15 \pm 5$ & 1,000 & $15 \pm 5$ & 0,622 & $0 \pm 0$ & 0,412 \\
\hline & A4 & $84 \pm 188$ & 1,000 & $13 \pm 5$ & 0,622 & $71 \pm 189$ & 0,412 \\
\hline
\end{tabular}

Values are in $\mathrm{mg} / \mathrm{mL}$, in mean drug doses. Mann-Whitney test, comparison with previous phase. $\mathrm{X} \pm \mathrm{SD}=\mathrm{Mean} \pm \mathrm{Standard}$ deviation; $\mathrm{A} 1, \mathrm{~A} 2, \mathrm{~A} 3, \mathrm{~A} 4=\mathrm{Baselines}$ TENS HF = high frequency transcutaneous electrical nerve stimulation; TENS LF = low frequency transcutaneous electrical nerve stimulation; TENS TO = turned-off transcutaneous electrical nerve stimulation. Significance level was $p<0.05$. 
LF, $\mathrm{p}=0.001$ ), and between baseline $\mathrm{A} 3$ and intervention $\mathrm{D}$ (turned-off TENS, $\mathrm{p}=0.044$ ), for participant 3 . For this same patient, comparison between interventions $\mathrm{B}$ with baseline A2, $\mathrm{C}$ with baseline $\mathrm{A} 3$ and $\mathrm{D}$ with baseline $\mathrm{A} 4$ were statistically significant $(\mathrm{p}=0.008)$.

These results are shown in figure 1, where three figures illustrate participants' answers to VAS along different study phases.
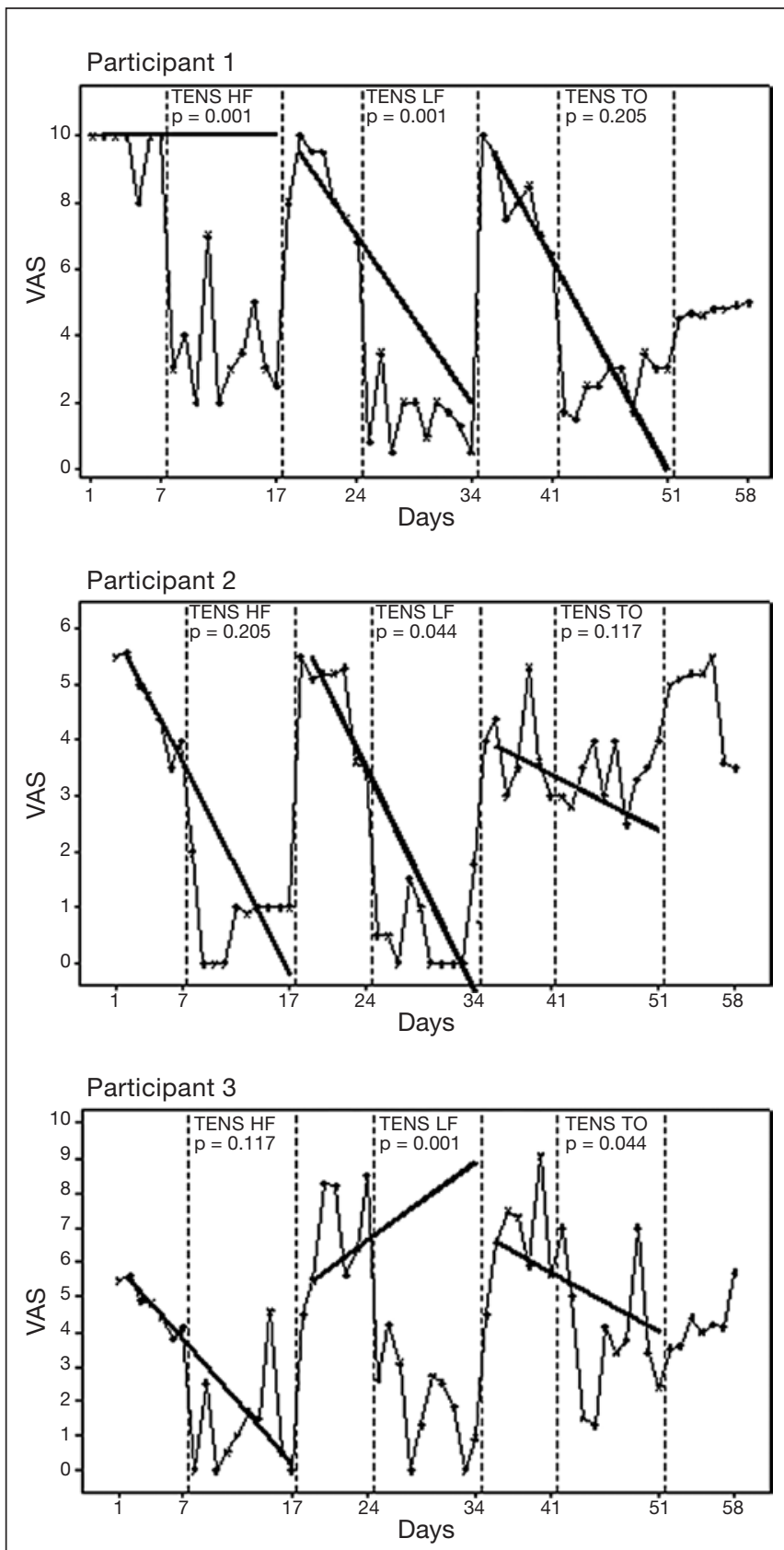

Figure 1. Participants' answers to visual analog scales along different study phases.

TENS HF = high frequency transcutaneous electrical stimulation; TENS LF = low frequency transcutaneous electrical stimulation; TENS TO = turned-off transcutaneous electrical stimulation (placebo). Straight lines show differences between previous baseline and next intervention by means of split middle line, with their respective $p$ values.

\section{DISCUSSION}

We decided for single subject design considering the small number of patients and also due not only to allocation difficulties caused by major symptoms of oncologic diseases stage IV in their rapid progression, but also to maintain middle and long term follow-up of interventions in these patients. It was also observed that most patients followed-up in this service via SUS lived in country towns, which made difficult their traveling for a more prolonged daily intervention period.

According to Sampaio et al. ${ }^{12}$ and Portney and Watkins ${ }^{13}$, single subject designs have as major characteristic patients' individual treatment, both with regard to decisions on the design itself and to data processing, which does not imply the use of a single subject per experiment.

Experimental single case study is widely used to check clinical evidences to determine the efficacy of a therapy and potential cause and effect relationship between intervention and target behavior, and is able to generate and test hypotheses. In this design model, patients are exposed to a series of conditions where body performance is repeatedly measured to check whether there is an ordinate relationship between conditions manipulated in the experiment and changes in such measurements, that is, a same patient is submitted to all experiment conditions and observations are continuously performed throughout the whole process. In addition, this type of design allows the evaluation of the effect of pain pattern measurements during the period without intervention - baseline - and after TENS intervention.

Our study has observed stability of baseline measurements, being this defined as a pattern with little variation along a certain period. In this type of design, stability of dependent variable measurements is a mandatory requirement, since values of dependent variable in different conditions are compared for each patient.

Precision and generality of conclusions of a single case design study are highly dependent on this stability. This strategy involves repeatedly measuring the dependent variable, pain, in conditions maintained constant until relatively stable data are obtained.

As it was possible to observe in results regarding analgesic drugs ingestion, it was observed that two participants ( 2 and 3 ) have significantly decreased total analgesic consumption while receiving TENS HF, being that one of them has also decreased total drug ingestion while receiving TENS LF (2). There has been significant analgesic consumption decrease in one volunteer receiving opioids (participant 3 ) and in two volunteers (participants 2 and 3) also receiving non-opioid analgesics after TENS HF intervention, being that one of them (participant 2) has also decreased non-opioid consumption after TENS LF. During turned-off TENS phase and in the follow-up period, baseline (4), there has been no significant analgesic consumption decrease.

These results confirm other studies ${ }^{18-20}$ which have observed decreased analgesic consumption between 25 and 30\% after 
HF and LF TENS application as compared to the placebo group in patients under analgesics, including opioids. This might be explained by TENS action mechanism, which is already accepted by its analgesic effects in some clinical disorders in physiotherapy ${ }^{15,18-20}$, where studies report increased blood and CSF B-endorphin concentrations in healthy subjects after administration of high and low frequency TENS ${ }^{4,5}$. There has also been increase in methionine-enkephalins and dynorphins A in lumbar CSF after treatment with LF or HF TENS, respectively. This suggest the release of different opioids with different electrical stimulation frequencies, to produce analgesia with high or low frequency TENS.

On the other hand, some authors ${ }^{21,22}$ have shown that TENS LF has induced analgesia by endogenous opioid release via $\mu$ receptor and that this could induce cross tolerance after prolonged opioid use. However, due to the type of experimental model proposed in this study, there were not enough data to observe such effect. Results, however, are encouraging for the development of further clinical studies to reproduce such effect.

As to pain intensity evaluation by participants after TENS application phases, results have shown that all participants had significant pain improvement after receiving TENS LF as compared to their respective previous and next baselines, that is, in this case there has been confirmation of intervention effects. So, it was shown that TENS LF applied to all participants with described demographic clinical profile had an effect, showing evidences of further efficacy in controlling pain as compared to TENS HF and turned-off TENS. These effects were probably due to TENS LF action mechanism which has shown more long lasting analgesic action as compared to TENS HF ${ }^{14}$. TENS LF action mechanism is not only the inhibition of spinal gates, but especially the activation of pain inhibitory descending system and modulation of the activity of transmission neurons located in spinal cord dorsal horn after endogenous opioids release. TENS LF effects are mediated by $\mu$-type opioid receptors ${ }^{4,21}$.

This study has also shown decreased pain intensity in a volunteer after TENS HF application (participant 1) and her respective previous and next baselines, and in two participants (participants 2 and 3) only as compared to their next baselines. In cases when the effect is only present after intervention withdrawal, that is, in next baseline, it is also suggested an action effect of TENS HF, although not so evident as that confirmed by significant difference between intervention and its previous and next baselines. TENS HF effects are basically due to its segmental inhibition mechanism, explained by spinal gates theory, where effects on spinal cord dorsal horn are short-lasting, lasting for a short time after removal of the stimulation, in addition to its action on $\mu$-type opioid receptors located on posterior spinal cord horn ${ }^{7,10}$. This is observed in the clinical practice where potent, however short-lasting effects are observed with TENS HF as compared to TENS LF.

It was expected that patients with tolerance to opioids would have a better response with TENS HF as compared to LF, by its action on $\mu$ opioid receptors which are those most affected in the mechanism of cross tolerance to opioids ${ }^{21,22}$. In our study, two participants were under regular drug use (participants 2 and 3), but only one (participant 3) was under frequent opioid use and in whom this cross tolerance effect was not observed, obtaining good responses both with TENS HF and with TENS placebo.

Unexpectedly, a statistically significant pain decrease after turned-off TENS was observed in participants as compared to their previous and next baselines. According to clinical characteristics of such patients, one may also observe that the placebo effect in this case was especially visible in the participant with marked depression classified by Beck Inventory (participant 3). This result confirms other authors ${ }^{8,10,11}$ that the placebo effect is a universal effect found in $20 \%$ to $30 \%$ of individuals, being responsible for clinical improvement of pharmacological and non-pharmacological analgesic procedures used in the clinical practice. According to studies 8 , the placebo effect really happens considering the affective-emotional aspect of pain which is easily modulated by psychological manipulations.

\section{CONCLUSION}

Although results being encouraging for the development of further clinical studies, a limitation of this study was the difficulty of volunteers in participating in the study, due to traveling difficulties and the presence of several common symptoms, such as exacerbated pain, in addition to nausea, malaise and vomiting.

Considering this experimental model, one may conclude that TENS was effective to decrease analgesic consumption for most participants, especially after HF, while TENS LF was also highly effective when analyzing VAS. However, other randomized controlled clinical trials are needed to check the effectiveness of TENS as non-pharmacological resource to decrease analgesic consumption and to control bone metastasis pain in breast cancer patients.

\section{REFERENCES}

1. Fromage B, Hatti M. [The pain experience according to a phenomenological view on palliative care]. Encephale. 2015;41(6):462-9. French.

2. Laird BJ, Fallon MT. Palliative care in the elderly breast cancer patient. Clin Oncol. 2009;21(2):131-9

3. Pena R, Barbosa LA, Ishikawa NM. Estimulaçăo elétrica transcutânea do nervo (TENS) na dor oncológica - uma revisăo da literatura. Rev Bras Cancerol. 2008;54(2):193-9.

4. Sluka KA, Walsh D. Transcutaneous electrical nerve stimulation: basic science mechanisms and clinical effectiveness. J Pain. 2003;4(3):109-21.

5. Han JS, Chen XH, Sun SL, Xu XJ, Yuan Y, Yan SC, et al. Effect of low- and high-frequency TENS on Met-enkephalin-Arg-Phe and dynorphin A immunoreactivity in human lumbar CSF. Pain. 1991;47(3):295-8.

6. Silva JG, Santana CG, Inocêncio KR, Orsini M, Machado S, Bergmann A. Electrocortical analysis of patients with intercostobrachial pain treated with TENS after breast cancer surgery. J Phys Ther Sci. 2014;26(3):349-53.

7. Loh J, Gulati A. The use of transcutaneous electrical nerve stimulation (TENS) in a major cancer center for the treatment of severe cancer-related pain and associated disability (Report). Pain Med. 2015;16(6):1204-10.

8. Robb K, Oxberry SG, Bennett MI, Johnson MI, Simpson KH, Searle RD. A cochrane systematic review of transcutaneous electrical nerve stimulation for cancer pain. J Pain Symptom Manage. 2009;37(4):746-53. 
9. Searle RD, Bennett MJ, Johnson MI, Callin S, Radford H. Transcutaneous electrical nerve stimulation (TENS) for cancer bone pain. J Pain Symptom Manage. 2009;37(3):424-8.

10. Benett MI, Johnson MI, Brown SR, Rodford H, Brown JM, Searle RD. Feasibility study of Transcutaneous Nerve Stimulation (TENS) for cancer bone pain. J Pain. 2010;11(4):351-9.

11. Almandil M, Kurmam R, Marido M. Randomized controlled trial comparing the effect different modes of TENS in reducing cancer pain. Physioterapy. 2015;101(Suppl 1):e57-8.

12. Sampaio AA, Azevedo FH, Cardoso LR, Lima C, Pereira MB, Andery MA. Uma introduçăo aos delineamentos experimentais de sujeito único. Inter Psicol. 2008;12(1):151-64.

13. Portney LS, Watkins MP. Foundations of clinical research. New Jersey: Prentice Hall Health; 2000.

14. Léonard G, Cloutier C, Marchand S. Reduced analgesic effect of acupuncture-like TENS but not conventional TENS in opioid-treated patients. J Pain. 2011;12(2):213-21.

15. Khadilkar A, Milne S, Brosseau L, Wells G, Tugwell P, Robinson V, et al. Transcutaneous electrical nerve stimulation for the treatment of chronic low back pain: a systematic review. Spine. 2005;30(23):2657-66.

16. Rhodes DJ, Koshy RC, Waterfield WC, Wu AW, Gossman SA. Feasibility of quantitative pain assessment in outpatient oncology practice. J Clin Oncol. 2001;19(2):501-8.
17. Andrade L, Gorenstein C, Vieira Filho AH, Tung TC, Artes R. Psychometric properties of the Portuguese version of the State-Trait Anxiety Inventory applied to college students: factor analysis and relation to the Beck Depression Inventory. Braz J Med Biol Res. 2001;34(3):367-74.

18. Bjordal JM, Johnson MI, Ljunggreen AE. Transcutaneous electrical nerve stimulation (TENS) can reduce postoperative analgesic consumption. A meta-analysis with assessment of optimal treatment parameters for postoperative pain. Eur J Pain. 2003;7(2):181-8.

19. Chen CC, Tabasam G, Johnson MI. Does the pulse frequency of transcutaneous electrical nerve stimulation (TENS) influence hypoalgesia? A systematic review of studies using experimental pain and healthy human participants. Physiotherapy. 2008;94(1):11-20

20. Ainsworth L, Budelier K, Clinesmith M, Fiedler A, Landstrom R, Leeper BJ, et al. Transcutaneous electrical nerve stimulation (TENS) reduces chronic hyperalgesia induced by muscle inflammation. Pain. 2006;120(1-2):182-7.

21. Resende MA, Gonçalves HH, Sabino GS, Pereira LS, Francischi JN. Redução do efeito analgésico da estimulação elétrica nervosa transcutânea de baixa frequência em ratos tolerantes à morfina. Rev Bras Fisioter. 2006;10(3):291-6.

22. Sluka KA, Judge MA, McColley MM, Reveiz PM, Taylor BM. Low frequency TENS is less effective than high frequency TENS at reducing inflammation-induced hyperalgesia in morphine-tolerant rats. Eur J Pain. 2000;4(2):185-93. 